\title{
Water Content and Ash Content of Corn Cob Ammoniation Fermentation Using Commercial Starters (M21 Decomposer)
}

\author{
Restuti Fitria $^{1}$, Dewi Puspita Candrasari ${ }^{2}$ dan Novita Hindratiningrum ${ }^{3}$ \\ ${ }^{1}$ Program Studi Peternakan, Universitas Nahdlatul Ulama Purwokerto \\ ${ }^{2}$ Program Studi Peternakan, Universitas Jenderal Soedirman \\ ${ }^{3}$ Program Studi Peternakan, Universitas Nahdlatul Ulama Purwokerto \\ restutifitria@gmail.com
}

\begin{abstract}
ABSTRAK
Janggel jagung merupakan limbah pertanian yang dapat dimanfaatkan sebagai pakan ternak khususnya ternak ruminansia. Janggel jagung mengandung selulosa cukup tinggi namun kecernaan rendah akibat adanya lignin yang tinggi. Oleh karena itu janggel jagung harus diolah terlebih dahulu untuk meningkatkan kualitasnya sebagai bahan pakan salah satunya dengan teknologi amoniasi fermentasi (amofer). Tujuan penelitian ini untuk mengevaluasi level penambahan M21 Dekomposer terhadap kualitas nutrisi amofer janggel jagung. Penelitian dilaksanakan menggunakan Rancangan Acak Lengkap (RAL). Perlakuan dalam penelitian ini adalah penambahan M21 Dekomposer atau aras starter komersial $(0 ; 0,02 ; 0,04 ; 0,06 \%$ dari total larutan formula). Variabel yang diamati meliputi kadar air dan kadar abu. Data yang diperoleh kemudian diolah menggunakan Analisis Variansi (ANAVA) dan dilanjutkan dengan Uji Beda Nyata Jujur (BNJ). Hasil diketahui bahwa perlakuan berpengaruh sangat nyata $(\mathrm{P}<0,01)$ baik terhadap kadar air dan kadar abu janggel jagung. Kadar air tertinggi $(33,74 \pm 0,59 \%)$ diperoleh pada perlakuan penambahan M21 Dekomposer sebanyak $0,02 \%$. Sedangkan kadar abu pada janggel jagung yang diamoniasi fermentasi dengan penambahan M21 Dekomposer lebih rendah $(1,89 \pm 0,14 \%)$ dibanding janggel jagung tanpa amofer. Kadar air yang meningkat disebabkan oleh adanya hasil dari proses fermentasi dan kadar abu yang lebih rendah pada janggel jagung yang diamofer menunjukan kadar bahan organik yang lebih tinggi.
\end{abstract}

Kata Kunci: Janggel Jagung, Amofer, Kadar Air, Kadar Abu.

\begin{abstract}
Corn cobs are an agricultural waste that can be used as a feed, especially for ruminants feed. Corn cobs are contain high cellulose but has a low digestibilty due to high lignin content. Therefore corn cobs must be processed first to improve its quality as a feed, one of which is ammoniation fermentation technology. The purpose of this study was to evaluate the addition level of M21 decomposer to the nutritional quality of corncob ammoniation fermentation. The research used experimental method according to Completely Randomized Designed. The treatments in this research was the addition of M21 decomposer or commercial starter level $(0 ; 0,02 ; 0,04 ;$ and $0,06 \%$ of the total formula solution). The observed variables included water and ash content. The obtained data was then processed using Analysis of Variance (ANOVA) and continued with a Honestly Significane Difference (HSD). The results of study showed that the treatment had a very significant effect $(\mathrm{P}<0,01)$ both on water content and ash content of corn cob. The highest water content $(33,74 \pm 0,59 \%)$ was obtained by the addition of $0,02 \%$ M21 Decomposer. Whereas the ash content of corn cob which was ammoniated fermented by M21 Decomposer was lower $(1,89 \pm 0,14 \%)$ than corn cob without ammoniation fermentation. Increased water content is caused by the results of fermentation process and lower ash content in corn cob which showed higher levels of organic matter.
\end{abstract}

Keywords: Corncob, Amofer, Water Content, Ash Content. 


\section{PENDAHULUAN}

Produksi jagung 5 tahun terakhir mengalami peningkatan rata-rata $12,48 \%$ per tahun (Direktorat Jenderal Tanaman Pangan, 2018). Produksi jagung pada tahun 2018 mencapai 30 juta ton pipilan kering dengan ratarata peningkatan luas panen per tahun mencapai $11,06 \%$ dan rata-rata peningkatan produktivitas mencapai 1,42\% (BPS, 2018). Janggel jagung yang merupakan limbah dari tanaman jagung dapat dimanfaatkan sebagai bahan pakan ternak terutama untuk ternak ruminansia karena masih mengandung selulosa dan hemiselulosa yang merupakan sumber energi utama bagi ternak ruminansia. Namun, kecernaan dan palatabilitas yang rendah sebagai akibat adanya kandungan lignin yang berikatan dengan selulosa membentuk lignoselulosa menyebabkan kualitas janggel jagung untuk dijadikan sebagai bahan pakan menjadi rendah (Umiyasih, 2008). Oleh karena itu, perlu dilakukan usaha untuk meningkatkan kualitas janggel jagung sehingga mampu meningkatkan kecernaan dan palatabilitasnya.

Penggabungan dua teknik antara amoniasi dan fermentasi atau disebut amofer adalah teknik yang dapat dilakukan dalam rangka meningkatkan kualitas janggel jagung sebagai bahan pakan ternak ruminansia. Amoniasi dapat meningkatkan kecernaan dengan cara melonggarkan ikatan lignin dengan selulosa (Pprastyawan et al., 2012) dan fermentasi dapat menguraikan bahan organik yang kompleks menjadi lebih sederhana dengan adanya aktivitas dari mikroorganisme (Riswandi et al., 2017). Aras stater komersial seperti M21 Dekomposer yang mengandung beberapa jenis mikrobakteri seperti Actinomycetes, Pseudomonas, Lactobacillus, Trichoderma, Acetobacter, dan Rhizobium dapat digunakan untuk mempercepat dan meningkatkan proses fermentasi. Namun, evaluasi terhadap level penggunaan M21 Dekomposer sebagai aras strater pada amofer janggel jagung perlu dilakukan. Amoniasi fermentasi pada janggel jagung diharapkan mampu meningkatkan kualitas nutrisi janggel jagung.

\section{MATERI DAN METODE}

\section{Materi Penelitian}

Materi yang digunakan dalam penelitian antara lain: janggel jagung, M21 Dekomposer, molases dan urea.

\section{Rancangan Percobaan}

Penelitian dilakukan dengan metode eksperimental dengan Rancangan Acak Lengkap (RAL) (Steel and Torrie, 1995). Terdapat 4 perlakuan dan 5 ulangan. Adapun perlakuan yang dicobakan yaitu level penambahan M21 Dekomposer.

R0 = Janggel jagung tanpa amofer (kontrol)

$\mathrm{R} 1$ = Janggel jagung diamofer dengan M21

Dekomposer $0,02 \%$

R2 = Janggel jagung diamofer dengan M21

Dekomposer $0,04 \%$

R3 = Janggel jagung diamofer dengan M21 Dekomposer $0,06 \%$

\section{Tahapan Penelitian}

\section{Tahap Persiapan}

Janggel jagung yang telah diambil bijinya dicacah dan digiling dengan menggunakan chooper .

M21 Dekomposer dikembangkan dengan penambahan M21 Dekomposer yang jumlahnya sesuai dengan perlakuan yakni $5 \mathrm{ml}(0,02 \%) ; 10 \mathrm{ml}$ $(0,04 \%)$; dan $15 \mathrm{ml}(0,06 \%)$ M21 Dekomposer kemudian masing-masing ditambah $250 \mathrm{ml}$ molases dalam 25 liter air. Dosis penggunaan $120 \mathrm{ml}$ per kg BK.

\section{Tahap Amoniasi}

Janggel jagung yang telah dicacah kemudian diamoniasi dengan cara basah dengan menambahkan urea sebanyak 3\% BK janggel jagung.

\section{Tahap Fermentasi}

Fermentasi dilakukan dengan menimbang $1 \mathrm{~kg}$ BK janggel jagung yang telah dicacah. Perlakuan pertama janggel jagung tanpa fermentasi (kontrol), perlakuan kedua janggel jagung difermentasi dengan larutan 0,02\% M21 Dekomposer, perlakuan ketiga janggel jagung difermentasi dengan larutan 0,04\% M21 Dekomposer dan perlakuan keempat janggel jagung difermentasi dengan larutan 0,06\% M21 Dekomposer. Masing-masing larutan M21 Dekomposer tersebut kemudian disiramkan pada janggel jagung hingga merata. Setelah masingmasing tercampur, kemudian dimasukkan ke dalam kantong plastik. Fermentasi berlangsung selama 2 minggu (Dewi et al., 2011).

\section{Persiapan Sampel dan Analisis}

Pembongkaran dilakukan setelah proses fermentasi selesai yaitu 2 minggu atau 14 hari. Janggel jagung kemudian dikeluarkan dalam kantong plastik, kemudian di oven selama 12 jam dengan suhu $65^{\circ} \mathrm{C}$ atau dapat menggunakan panas matahari (sampai 
beratnya konstan). Janggel jagung kemudian dihaluskan dengan menggunakan blender. Janggel jagung siap digunakan untuk analisis proksimat.

Variabel Penelitian dan Analisis Data

Variabel yang diamati dalam penelitian adalah kadar air dan kadar abu janggel jagung.

\section{HASIL DAN PEMBAHASAN}

- Hasil analisis kadar air dan kadar abu janggel jagung tersaji pada Tabel 1 .

\begin{tabular}{ccc}
\hline Perlakuan & Kadar Air (\%) & Kadar Abu (\%) \\
\hline $\mathrm{R}_{0}$ & $11,34 \pm 0,49^{\mathrm{c}}$ & $1,89 \pm 0,14^{\mathrm{a}}$ \\
$\mathrm{R}_{1}$ & $33,74 \pm 0,59^{\mathrm{a}}$ & $1,59 \pm 0,12^{\mathrm{b}}$ \\
$\mathrm{R}_{2}$ & $28,44 \pm 2,27^{\mathrm{b}}$ & $1,50 \pm 0,09^{\mathrm{b}}$ \\
$\mathrm{R}_{3}$ & $30,27 \pm 0,26^{\mathrm{b}}$ & $1,54 \pm 0,10^{\mathrm{b}}$
\end{tabular}

Superscript yang sama pada kolom yang sama menunjukan tidak adanya perbedaan dan seperscript yang berbeda pada kolom yang sama menunjukan adanya perbedaan.

Keterangan:

R0 = Janggel jagung tanpa amofer (kontrol)

R1 = Janggel jagung diamofer dengan M21 Dekomposer 0,02\%

R2 = Janggel jagung diamofer dengan M21 Dekomposer 0,04\%

R3 = Janggel jagung diamofer dengan M21 Dekomposer 0,06\%

Analisis variansi menunjukan bahwa perlakuan sangat berpengaruh nyata $(\mathrm{P}<$ 0.01) baik terhadap kadar air maupun kadar abu janggel jagung. Uji lanjut BNJ menunjukan kadar air tertinggi $(\mathrm{P}<0,01)$ diperoleh pada perlakuan $\mathrm{R} 1$ dibanding perlakuan R2, R3 dan R0. Namun, perlakuan $\mathrm{R} 2$ dan R3 tidak berbeda nyata $(\mathrm{P}>0,05)$. Kadar air terendah diperoleh pada perlakuan R0 (P > 0.01). Sedangkan kadar abu tertinggi $(\mathrm{P}<0,01)$ diperoleh pada perlakuan R0 dibanding perlakuan R1, R2 dan R3. Namun, kadar abu pada perlakuan R1, R2 dan R3 tidak berbeda nyata $(\mathrm{P}>0,05)$.

Kadar air yang meningkat pada janggel jagung yang diberi perlakuan amofer (R1, R2 dan R3) menunjukan bahwa proses amofer yang terjadi pada janggel jagung berlangsung dengan baik. Proses fermentasi menghasilkan $\mathrm{H} 2 \mathrm{O}$ dan hal ini yang menyebabkan kadar air pada janggel jagung meningkat. Fermentasi aerob (oksidasi sempurna) menghasilkan $\mathrm{CO} 2$, air dan asam organik (Schlegel dan Schmidt, 1994).

Kadar abu pada janggel jagung yang mendapat perlakuan amofer (R1, R2 dan R3) memiliki kadar abu yang lebih rendah dibanding janggel jagung tanpa amofer (R0). Namun, kadar abu baik pada R1, R2 dan R3 tidak berbeda nyata $(\mathrm{P}>0,05)$. Kadar abu merupakan campuran mineral dan bahan anorganik dari suatu bahan pakan. Bahan kering suatu bahan pakan dalam analisis proksimat tersusun atas kadar abu dan bahan organik (AOAC, 2005). Hal ini dapat menunjukan bahwa kadar bahan organik pada amofer janggel jagung (R1, R2 dan R3) lebih tinggi dibanding pada janggel jagung tanpa amofer (R0). Menurut Cherney (2000) kandungan bahan organik suatu pakan terdiri dari protein kasar, lemak kasar, serat kasar dan bahan ekstrak tanpa nitrogen (BETN). Lebih tingginya kadar bahan organik pada amofer janggel jagung menunjukan adanya peningkatan kualitas nutrisi janggel jagung. Selain itu, kualitas fisik janggel jagung yang mendapat perlakuan amofer dengan penambahan M21 Dekomposer baik pada level $0,02 \%, 0,04 \%$ dan $0,06 \%$ yang menunjukan perubahan warna menjadi coklat (browning) dan perubahan tekstur menjadi lebih lunak dapat mengindikasikan adanya proses kimiawi dan peningkatan kualitas nutrisi sebagai akibat adanya perlakuan amoniasi fermentasi (Fitria dan Dewi, 2019)

\section{KESIMPULAN}

Perlakuan amoniasi fermentasi menggunakan M21 Dekomposer pada janggel jagung mampu meningkatkan kualitas nutrisi janggel jagung dimana penurunan kadar abu pada janggel jagung yang diamofer menunjukan kadar bahan organik yang mengalami peningkatan.

\section{REFERENSI}

AOAC, 2005. Official Methods of Analysis. Association of Official Analytical Chemists. Benjamin Frankli Station, Washington

Biro Pusat Statistik Indonesia. 2018. Food Crop Statistics. http://www.bps.go.id. Diakses tanggal 22 Mei 2019.

Cherney, D.J.R. 2000. Characterization of Forages by Chemical Analyssis. Dalam: Forage Evaluation in Ruminant Nutrition. CABI Publishing, New York. Hal 281- 300.

Dewi, H., Shofia, N.A., dan Baginda, I.M. 2011. Pengaruh Perlakuan Teknologi Amofer (Amoniasi Fermentasi) pada Limbah Tongkol Jagung sebagai Alerrnatif Pakan Berkualitas Ternak Ruminansia. Mediagro, Vol. 7 No. 1, hal: $55-65$. 
Direktorat Jenderal Tanaman Pangan. 2018. Data ProduksiJagung.http://www.tanamanpangan. pertanian.go.id. Diakses tanggal 22 Mei 2019

Dwi, Y., W. Puastuti, E. Wina dan Supriati. 2012. Pengaruh berbagai Pengolahan terhadap Nilai Nutrisi Tongkol Jagung: Komposisi Kimia dan Kecernaan In Vitro. Jurnal Ilmu Ternak dan Veteriner, Vol. 17, No. 1: 59 66.

Fitria, R. dan Dewi P.C. 2019. Kualitas Fisik Amoniasi Fermentasi (AMOFER) Janggel Jagung dengan Penambahan M21 Dekomposer pada Level yang Berbeda. Bulletin of Applied Animal Research, Vol 1, No. 1: 35 - 39.

Pprastyawan, R.M., B.I.M Tampoebolon dan Surono. 2012. Peningkatan Kualitas Janggel Jagung melalui Teknologi Amoniasi Fermentasi (AMOFER) terhadap Kecernaan Bahan Kering dan Bahan Organik serta Protein Total secara In Vitro. Animal Agriculture Journal, Vol. 1. No. 1, 2012, p $611-621$.

Riswandi, S. Sandi, and I.P. Sari. 2017. Amoniasi Fermentasi (Amofer) Serat Sawit denga Penambahan Urea dan Effectie Microorganism-4 (EM-4) terhadap Kualitas Fisik, Derajat Keasaman (pH), Bahan Kering dan Bahan Organik. Prosiding Seminar Nasional Lahan Suboptimal 2017, Palembang 19 - 20 Oktober 2017.

Schlegel, H.G. dan K. Schmidt. 1994. Mikrobiologi Umum. Gadjah Mada university presss, Yogyakarta (diterjemahkan oleh T. Baskoro dan J.R. Wattimena).

Steel, R. G. D and J.H. Torrie. 1995. Principles and Procedures of Statistics. Alih Bahasa Sumantri, B. Prinsip dan Prosedur Statistika. Edisi 4 Penerbit P.T. Gramedia Pustaka Utama, Jakarta.

Umiyasih, U., dan E. Wina. 2008. Pengolahan dan Nilai Nutrisi Limbah Tanaman Jagung sebagai Pakan Ternak Ruminansia. Wartazoa. 18(3). 